\title{
The Relevance of Learning Approaches and Temporal Perspective for Test-Taking
}

Andreja Bubić ${ }^{1}$

$\approx$ Test-taking is an integral part of students' lives, and the way they approach tests may be of high relevance for their academic outcomes. Therefore, the present study addressed the way college students reflect on the process of preparing for tests. Specifically, it investigated the relevance of students' achievement goals, perceived academic control, and consideration of future consequences for several aspects of the testtaking process. The results obtained revealed mastery goals, perceived academic control, and the ability to disengage from the present moment as significant predictors of students' satisfaction with knowledge. Furthermore, higher success optimism was associated with having higher perceived academic control, more pronounced mastery goals, less pronounced social solidarity goals, and a higher tendency to focus on the future, whereas perceived academic control was revealed to be a significant predictor of the perceived ease of preparing for tests.

Keywords: achievement goals, consideration of future consequences, higher education, perceived academic control, test-taking 


\section{Pomembnost učnih pristopov in časovni pogled na opravljanje preizkusov znanja}

ANDreja Bubić

$\propto$ Opravljanje preizkusov znanja je sestavni del življenja študentov; način, na katerega pristopajo k opravljanju preizkusov, je lahko zelo pomemben za njihove študijske dosežke. Zato se je zadevna raziskava ukvarjala $z$ ugotavljanjem načina, na podlagi katerega študentje razmišljajo o procesu priprave na opravljanje preizkusov. Raziskava se je osredinila zlasti na pomembnost izvedbenih ciljev, zaznan akademski nadzor in na premislek o prihodnjih posledicah za različne vidike postopka opravljanja preizkusov znanja. Pridobljeni rezultati so pokazali, da so visoki cilji, zaznan akademski nadzor in sposobnost odmika od sedanjosti pomembni napovedovalci zadovoljstva študentov z znanjem. Poleg tega je bila višja stopnja optimizma glede uspeha povezana $z$ večjo zaznano stopnjo akademskega nadzora, bolj izraženimi visokimi cilji, z manj izraženimi cilji glede družbene solidarnosti in $z$ večjo težnjo po usmerjenosti v prihodnost, medtem ko se je zaznan akademski nadzor izkazal kot ključni dejavnik napovedi zaznane preproste priprave na opravljanje preizkusov.

Ključne besede: izvedbeni cilji, upoštevanje prihodnjih posledic, univerzitetno izobraževanje, zaznan akademski nadzor, opravljanje preizkusov znanja 


\section{Introduction}

Obtaining a college degree is a process that involves not only learning and participating in various academic activities but also demonstrating the acquired knowledge and skills that is typically accomplished through various forms of evaluative events, namely tests. Although the format of such tests generally varies across teachers, subjects, schools, and education levels, test-taking is a process that always includes a forethought or preparatory phase during which students prepare for the test, a performance phase during which they take the test, and a self-reflection phase during which they reflect on the results of the test (Schutz \& Davis, 2000; Zimmerman, 1998, 2000). All of these phases may be very cognitively and emotionally demanding for students, and often require a considerable amount of self-regulation efforts and skills (Schutz \& Davis, 200o). Interestingly, although most students are typically very motivated to provide their best performance in testing situations, their perception of their efforts and progress is not always objective and realistic. Specifically, it has been demonstrated that students tend to experience difficulties judging their readiness and performance on tests, even in college (Peverly et al., 2003; Pressley \& Ghatala, 1988; Pressley et al., 1990).

The self-reflection phase (Zimmerman, 1998, 2000) is a vital part of the test-taking process because, although it may not influence the outcomes of completed tests, this period can provide students with an opportunity to reflect on their previous behaviours and learning. During this time, learners' satisfaction with the acquired knowledge and the achieved grades, as well as their perception of actions undertaken while preparing for tests, may provide strong motivation and guidance for changing future behaviours. Therefore, this phase offers students a unique opportunity to develop deeper metacognitive insights (Brown, 1978; Flavell, 1979; Veenman et al., 2006) that may allow them to accomplish more favourable outcomes in the future. Consequently, it is crucial to better understand students' considerations of their behaviours and performance during this phase, as well as factors that influence these.

\section{The Role of Academic Motivation and Perceived Academic Control in Students' Educational Outcomes}

Among different determinants of students' academic behaviours and outcomes, numerous studies have previously demonstrated that motivation, achievement goals, and views of one's abilities are some of the most relevant factors associated with individuals' success and attributions of one's success in the academic domain (Nilsen, 2009; Pajares, 2003). Consequently, various theoretical 
conceptualisations have thus far been developed that offer different approaches to understanding student motivation. A number of these theories has recognised the relevance of individuals' expectations regarding the outcomes, subjective value of the task, and achievement goals that reflect the purpose of one's engagement in a specific activity (Eccles, 2005; Eccles \& Wigfield, 2002; Wigfield \& Eccles, 2000, 2002). Within the Personal Investment Theory (Maehr, 1984; Maehr \& Braskamp, 1986), such goals are defined as students' beliefs regarding the purpose of academic work, achievement, and success (Urdan \& Maehr, 1995). According to this theory, it is possible to distinguish between four types of relatively stable achievement goals that include mastery (task), performance (ego), social solidarity (social relations), and extrinsic goals (Maehr, 1984; McInerney et al., 2002; McInerney et al., 1997). Among these, mastery or task goals are directed towards knowledge, learning, and tasks, and are utilised by students who typically have good self-regulatory skills, use deep processing strategies, and experience more positive emotions during learning (Covington, 2000; Urdan \& Maehr, 1995). In contrast, performance or ego goals reflect individuals' strivings towards accomplishing socially acceptable standards and excel in performance when compared to others. Next, extrinsic goals are related to learning because of rewards received from others, whereas social solidarity achievement goals reflect individuals' attempts to belong to a peer group or gain the approval of others.

In addition to students' achievement goals, academic behaviours and success are also related to their views of their characteristics and potentials. One aspect of such beliefs includes perceived academic control that reflects individuals' beliefs regarding their abilities and other characteristics that are relevant for academic success and the accomplishment of favourable educational outcomes (Perry, 1991; Perry et al., 2001). Similarly to the related construct of academic selfefficacy, perceived academic control influences individuals' motivation, academic achievement as well as emotions typically experienced in school (Bandura, 1977; Multon et al., 1991; Robbins et al., 2004; Schunk et al., 2008; Zimmerman \& Kitsantas, 1997).

\section{The Relevance of Temporal Perspective for Students' Educational Outcomes}

In addition to the described characteristics that are specifically associated with the educational domain, individuals' academic outcomes are also influenced by other characteristics, such as abilities, interests, personality traits, or emotions (Slavin, 1991). Furthermore, persons' cognitive and decision-making styles, namely ways that they typically collect, process, and use information in 
decision-making situations, may also be of relevance in this context (Appelt et al., 2011). Among these, the present study explored one aspect of individuals' temporal perspective: the tendency to explicitly consider the potential future outcomes of actions (Strathman et al., 1994). Specifically, it has previously been demonstrated that people differ with respect to their tendency to focus on the present moment and the willingness to sacrifice immediate wishes in order to secure the desired future outcomes (Strathman et al., 1994a; Zimbardo \& Boyd, 1999). Earlier studies that have investigated this characteristic have indicated that individuals who carefully consider future consequences more frequently engage in different types of responsible behaviours (Joireman et al., 2008; Joireman et al., 2001; Moore \& Dahlen, 2008; Strathman et al., 1994a; Strathman \& Joireman, 2005). Similar to other domains, within the educational context such individuals invest more efforts and persist in academic activities, indicating the relevance of this trait for their motivation, self-regulation and academic achievement (Bembenutty \& Karabenick, 2004; Husman \& Lens, 1999; Joireman et al., 2008; Malka \& Covington, 2005; McInerney, 2004; Taber, 2013).

\section{Research Questions and Hypotheses}

The present study focused on the self-reflection phase of the test-taking process, during which students consider test results, and investigated the way they reflect on the process of preparing for tests, its outcomes, and expectations regarding future success. Specifically, within this study, college students majoring in the social sciences and humanities in Croatia assessed their perceived ease of preparing for tests during the previous year, satisfaction with knowledge acquired while preparing for tests, and optimism regarding success in completing future tests. Next, we addressed the importance of several characteristics whose impact on other segments of students' academic behaviours has previously been described, namely perceived academic control, achievement goals and the tendency to consider future consequences, for these criteria.

In doing so, it was hypothesised that mastery goals would be associated with higher commitment to the process of preparing for tests, resulting in students' higher satisfaction with the knowledge acquired while preparing for tests and higher optimism with respect to achieving success in future tests. Next, we expected that higher perceived academic control would be associated with a more dedicated and successful approach to test-taking, which would be reflected in students' higher satisfaction with the knowledge acquired while preparing for tests and higher optimism regarding future success. Furthermore, given that students with higher perceived academic control view their abilities 
in a more favourable light, they were expected to perceive the process of preparing for tests as being easier than those students characterised by lower perceived academic control. Finally, within the present study, it was hypothesised that individuals who carefully consider future consequences would be more responsible with respect to the way they approach test-taking, which would result in their higher satisfaction with the knowledge acquired while preparing for tests as well as higher optimism regarding future success.

\section{Method}

\section{Sample and Procedure}

Among 291 college students (average age $M=21.32$ years, $S D=1.98$ ) who participated in the present study, 15 (5.2\%) were male and 276 (94.8\%) female. The participants were all students majoring in different social studies (e.g., sociology, pedagogy) and humanities (e.g., history, art history, philosophy) at the University of Split, Croatia. Participants were approached at the college premises during their lectures. There, they completed the prepared questionnaires within a group setting for course credit. The following instruments were used in the present study: Perceived Academic Control Scale (Perry et al., 2001), Consideration of Future Consequences Scale (Strathman et al., 1994) and the Inventory of School Motivation (McInerney et al., 1997; McInerney et al., 2000; McInerney \& Sinclair, 1991, 1992). In addition, the participants reported the perceived ease of preparing for tests using a five-point Likert-type response scale (1 - very easy; 5 - very difficult). Furthermore, they reported their level of satisfaction with the knowledge acquired while preparing for previous tests using a five-point Likerttype response scale ( 1 - completely unsatisfied; 5 - completely satisfied), and optimism regarding their chances of successfully completing future tests (success optimism) using a five-point Likert-type response scale (1 - very pessimistic; 5 - very optimistic). Their reported ease of preparing for previous tests was 2.95 $(S D=.63)$, satisfaction with the knowledge acquired while preparing for previous tests $3.66(S D=.76)$, and optimism regarding future chances for success 4.45 $(S D=.74)$.

\section{Instruments}

The Perceived Academic Control Scale (Perry et al., 2001) is a questionnaire used for measuring students' perceived academic control that reflects their beliefs regarding the capacity to influence their academic outcomes. This scale comprises eight items (e.g., My grades are basically determined by things beyond my control, and there is little I can do to change that) that the participants 
rated on a five-point Likert type scale (1 - strongly disagree; 5 - strongly agree). Among them, four items, including the presented one, were negatively phrased and therefore reverse scored. A higher score on this scale reflects a higher degree of perceived academic control.

The Consideration of Future Consequences Scale (Strathman et al., 1994b) is a 12-item instrument used for assessing the extent to which individuals focus on the short-term or long-term consequences of their actions. As previous studies have indicated a two-factorial structure of this scale, within the present study, participants' scores were calculated separately for two distinct subscales: one reflecting present-oriented, and one future-oriented tendencies (Bubic, 2015; Joireman et al., 2008). The first, the Present Focus scale, comprises seven items that primarily describe individuals' tendency to focus on the current moment (e.g., I only act to satisfy immediate concerns, figuring out the future will take care of itself). In contrast, the Future Focus scale comprises five items that describe individuals' willingness to disengage from the present and consider the future (e.g., I am willing to sacrifice my immediate happiness or well-being in order to achieve future outcomes). A higher score on these scales reflects a higher degree of present and future orientation, respectively.

The Inventory of School Motivation (McInerney et al., 1997, 2000; McInerney \& Sinclair, 1991, 1992) is an instrument that measures different types of achievement goals that include mastery (task and effort), performance or ego (competition and social power), social solidarity (affiliation and social concern), and extrinsic goals (praise and token rewards). The whole instrument comprises 43 items that the participants rated on a four-point Likert type scale ( 1 - strongly disagree; 4 - strongly agree). Among these, 11 items are used for measuring mastery goals (e.g., When I am improving in my schoolwork I try even harder), 12 for measuring performance or ego goals (e.g., I like to compete with others at school), 8 for measuring social solidarity goals (e.g., I prefer to work with other people at school rather than work alone), and 12 for measuring extrinsic goals (e.g., I work best in class when I get some kind of rewards). A higher score on these scales reflects a higher degree of each achievement goal, respectively. 
Table 1

Psychometric Properties of the Administered Instruments

\begin{tabular}{lccccc}
\hline Measure & $M$ & SD & Min & Max & Cronbach $\alpha$ \\
\hline Present focus & 18.99 & 5.02 & 8 & 32 & .81 \\
Future focus & 18.75 & 3.27 & 9 & 25 & .73 \\
Mastery goals & 36.07 & 4.09 & 22 & 44 & .80 \\
Performance goals & 19.14 & 5.99 & 12 & 45 & .90 \\
Social solidarity goals & 24.67 & 4.02 & 13 & 32 & .81 \\
Extrinsic goals & 24.48 & 7.06 & 12 & 47 & .89 \\
Perceived academic control & 32.88 & 4.06 & 19 & 40 & .74 \\
\hline
\end{tabular}

\section{Results}

Correlation analyses were conducted as the first step in investigating the relations among the explored variables. The results revealed positive correlations among participants' mastery goals, perceived academic control, satisfaction with acquired knowledge, and success optimism. Furthermore, a positive correlation between mastery goals and future focus, as well as a negative correlation between these goals and present focus were also revealed. The remaining correlations are presented in Table 2.

Table 2

\section{Correlation Matrix for the Tested Variables}

\begin{tabular}{|c|c|c|c|c|c|c|c|c|c|}
\hline & 2 & 3 & 4 & 5 & 6 & 7 & 8 & 9 & 10 \\
\hline Present focus (1) & $-.13^{\circ}$ & $-.19^{* *}$ & -.05 & -.01 & .01 & $-.16^{*}$ & -.05 & $-.19^{* *}$ & -.04 \\
\hline Future focus (2) & & $.39 *$ & $.24 "$ & $.13^{*}$ & $.19^{*}$ & $.18^{* *}$ & .03 & .04 & $.23^{*}$ \\
\hline Mastery goals (3) & & & $.25^{* \prime}$ & $.21^{*}$ & $.23^{* \prime}$ & $.28^{*}$ & .10 & $.26^{*}$ & $.31^{*}$ \\
\hline Performance goals (4) & & & & -.10 & $.59^{* *}$ & -.06 & .09 & -.06 & .05 \\
\hline Social solidarity goals (5) & & & & & .04 & .05 & .11 & .07 & $-.12^{*}$ \\
\hline Extrinsic goals (6) & & & & & & .01 & $.12^{*}$ & .02 & -.02 \\
\hline Perceived academic control (7) & & & & & & & $-.22^{* *}$ & $.21^{* *}$ & $.29 *$ \\
\hline Ease of preparing for tests ( 8 ) & & & & & & & & .09 & $-.14 *$ \\
\hline Satisfaction with acquired knowledge (9) & & & & & & & & & $.15^{\circ}$ \\
\hline Optimism regarding future tests (10) & & & & & & & & & \\
\hline
\end{tabular}

Note: ${ }^{*} p<.05 ;{ }^{* *} p<.01$. 
Next, the relationships among the investigated variables were explored in more detail using three hierarchical regression analyses in which students' perceived ease of preparing for tests, satisfaction with knowledge acquired while preparing for tests, and optimism regarding success in future tests served as criteria. Within these analyses, participants' present and future focus were entered in the first step on the analyses as domain-unspecific individuals' characteristics associated with their general decision-making tendencies. Four types of achievement goals were entered in the next step of the analyses, whereas perceived academic control was entered as the last potential predictor in the third step (Table 3). The conducted analysis in which the ease of preparing for tests served as a criterion indicated that the regression model became significant only in the last step of the analysis, after including perceived academic control in the model, which then explained $10 \%$ of the variance. In contrast, regression models in which satisfaction with knowledge and success optimism served as criteria reached significance in the first step of the analyses, at which point individuals' general temporal perspectives explained $4 \%$ and $5 \%$ of the variance, respectively. Although their contributions were not high, it has to be noted that temporal orientations represent individuals' characteristics that are not related to any specific context but reflect their general decision-making tendencies. Not surprisingly, the amount of explained variance increased after including academically-specific predictors in later steps of the analyses and reached $12 \%$ for satisfaction with knowledge and $20 \%$ for success optimism.

Overall, the obtained results revealed mastery goals and perceived academic control as significant predictors of students' satisfaction with knowledge and success optimism. Furthermore, future focus was identified as a significant predictor of success optimism, whereas present focus was negatively associated with students' satisfaction with knowledge. In addition, lower levels of social solidarity goals predicted higher success optimism among students. Finally, perceived academic control was identified as a significant predictor of students' perceived ease of preparing for tests. Although performance goals did not significantly contribute to any addressed criteria, they were identified as a predictor of satisfaction with knowledge after the second step of the analysis but lost their significance after including perceived academic control in the model. 
Table 3

Results of the Regression Analyses using Ease of Preparing for Tests, Satisfaction with Acquired Knowledge, and Optimism Regarding Future Tests as Criteria

\begin{tabular}{|c|c|c|c|c|}
\hline \multirow[b]{2}{*}{ Steps } & \multirow[b]{2}{*}{ Predictors $(\beta)$} & \multicolumn{3}{|c|}{ Criteria } \\
\hline & & $\begin{array}{l}\text { Ease of preparing } \\
\quad \text { for tests }\end{array}$ & $\begin{array}{c}\text { Satisfaction } \\
\text { with acquired } \\
\text { knowledge }\end{array}$ & $\begin{array}{l}\text { Optimism } \\
\text { regarding future } \\
\text { tests }\end{array}$ \\
\hline \multirow{5}{*}{1.} & Present focus & -.04 & $-.18^{* *}$ & -.02 \\
\hline & Future focus & .03 & .02 & $.22^{* *}$ \\
\hline & $\mathrm{R}$ & .05 & .19 & .23 \\
\hline & $\mathrm{R}^{2}$ & .00 & .04 & .05 \\
\hline & $F(d f)$ & $.39(2,288)$ & $5.16^{* *}(2,288)$ & $7.76^{* *}(2,288)$ \\
\hline \multirow{10}{*}{2.} & Present focus & -.04 & $-.15^{*}$ & .04 \\
\hline & Future focus & -.03 & -.06 & $.16^{* *}$ \\
\hline & Mastery goals & .05 & $.28^{* *}$ & $.33^{* *}$ \\
\hline & Performance goals & .04 & $-.16^{*}$ & -.04 \\
\hline & Social solidarity goals & .11 & .00 & $-.21^{* *}$ \\
\hline & Extrinsic goals & .09 & .07 & -.09 \\
\hline & $\mathrm{R}$ & .18 & .33 & .40 \\
\hline & $\mathrm{R}^{2}$ & .03 & .11 & .16 \\
\hline & $\Delta \mathrm{R}^{2}(95 \% \mathrm{Cl})$ & $.03(0-.07)$ & $.07^{* *}(.01-.13)$ & $.11^{* *}(.04-.18)$ \\
\hline & $F(d f)$ & $1.58(6,284)$ & $5.75^{* *}(6,284)$ & $9.19^{* *}(6,284)$ \\
\hline \multirow{11}{*}{3.} & Present focus & -.07 & $-.14^{*}$ & .06 \\
\hline & Future focus & -.01 & -.07 & $.13^{*}$ \\
\hline & Mastery goals & .12 & $.25^{* *}$ & $.28^{* *}$ \\
\hline & Performance goals & -.01 & -.14 & .00 \\
\hline & Social solidarity goals & .10 & .00 & $-.20^{* *}$ \\
\hline & Extrinsic goals & .10 & .06 & -.10 \\
\hline & Perceived academic control & $-.27^{* *}$ & $.12^{*}$ & $.21^{* *}$ \\
\hline & $\mathrm{R}$ & .31 & .35 & .45 \\
\hline & $\mathrm{R}^{2}$ & .10 & .12 & .20 \\
\hline & $\Delta \mathrm{R}^{2}(95 \% \mathrm{Cl})$ & $.06^{* *}(.01-.11)$ & $.01^{*}(0-.03)$ & $.04^{* *}(0-.08)$ \\
\hline & $F(d f)$ & $4.25^{* *}(7,283)$ & $5.58^{* *}(7,283)$ & $10.22^{* *}(7,283)$ \\
\hline
\end{tabular}

Note: ${ }^{*} p<.05 ;{ }^{* *} p<.01$. 


\section{Discussion}

The present study focused on the self-reflection phase of the test-taking process that represents a crucial part of students' academic lives and strongly impacts their final learning outcomes and achievements. In doing so, it investigated the relevance of students' achievement goals, perceived academic control and consideration of future consequences for their evaluations of the test-taking process, namely the perceived ease of preparing for tests, satisfaction with knowledge acquired while learning for tests, as well as optimism regarding success in completing future tests. The results obtained identified perceived academic control, mastery achievement goals, and the ability to disengage from the present moment as significant predictors of students' satisfaction with knowledge. In addition, perceived academic control was revealed to be a predictor of the perceived ease of preparing for tests. Finally, individuals' perceived academic control, higher levels of mastery goals, lower levels of social solidarity and the tendency to focus on the future were identified as significant predictors of success optimism.

\section{The Role of Academic Motivation and Perceived Academic Control in Students' Educational Outcomes}

First, the present study revealed the relevance of participants' achievement goals with respect to their satisfaction with knowledge acquired while preparing for tests and optimism regarding success in future tests. Specifically, higher levels of mastery goals were associated with both of these outcomes, whereas less pronounced social solidarity goals were related to higher optimism regarding future success. With respect to the mastery goals, the obtained findings are not surprising, as these goals reflect individuals' strivings towards knowledge and learning (Maehr, 1984; McInerney et al., 2002; McInerney et al., 1997; Urdan \& Maehr, 1995). Consequently, individuals who develop such goals would be expected to learn more while preparing for tests, and should, therefore, be more satisfied with the acquired knowledge. As indicated by the obtained results, such experiences would also allow them to develop more optimistic expectations regarding their success on future exams, as such predictions are typically formulated based on previous experiences (Bandura, 2006; Maddux, 1999). With respect to the social solidarity goals, the findings indicating its negative association with success optimism were not expected. However, these may be interpreted if we consider the fact that individuals who are oriented towards social relations and helping others generally, as well as in academic settings, may have different values and priorities when compared to those who are oriented towards learning or achieving more (Covington, 2000; 
Urdan \& Maehr, 1995). Although such strivings often converge with other academic goals, in some situations they can also conflict, in which case students may place more value on social relations than learning itself (Dowson \& McInerney, 2001, 2003; Wentzel, 1996, 1999; Wentzel \& Wigfield, 1998). Therefore, these individuals may not always consider their future academic achievements with such care or reflect on them in great depth, potentially resulting in their lower expectations of future accomplishments.

Next, within the present study, perceived academic control was revealed to be a significant predictor of students' perceived ease of preparing for tests, their satisfaction with knowledge acquired while preparing for tests as well as optimism regarding potential success in future tests. Such a role of this characteristic in the present context was expected, as previous studies have indicated the relevance of different types of students' views of their abilities for their academic accomplishments and outcomes (Bandura, 1986; Bandura et al., 1996; Pajares \& Urdan, 2006; Perry, 1991; Perry et al., 2001). Given that students with higher perceived academic control tend to view their abilities in a favourable light, they also evaluated the process of preparing for tests as easier than those characterised by lower perceived academic control. Furthermore, as such students typically invest more efforts and are more dedicated to learning (Bandura, 1986; Perry et al., 2005; Schunk, 1990, 1991; Sorić \& Burić, 2010; Zimmerman, 1995), it is not surprising that they were also more satisfied with their accomplishments. This resonates with previous studies indicating that self-efficacy and perceived academic control are related not only to students' higher academic achievement, but also to higher satisfaction with school (Ainley et al., 1991; Mok \& Flynn, 2002; Raboteg-Šarić et al., 2009). The present study indicates that this satisfaction also extends to their views of their accomplishments and outcomes. In addition to showing higher satisfaction with the acquired knowledge, students with higher perceived academic control also posited more favourable expectations for the future. The relevance of such expectations has been repeatedly demonstrated in the context of social cognitive theory (Bandura, 2006), indicating that these may not only facilitate future success but are also related to individuals' increased well-being and satisfaction (Cummins \& Nistico, 2002).

\section{The Relevance of Temporal Perspective for Students' Educational Outcomes}

Finally, the present study revealed the relevance of one aspect of participants' temporal perspective, namely the consideration of future consequences, for their satisfaction with acquired knowledge and optimism regarding future 
success. Specifically, whereas the ability to disengage from the present moment predicted students' satisfaction with knowledge, a higher tendency to focus on the future was associated with higher success optimism. The general impact of these traits in the present context was expected, as it has previously been repeatedly demonstrated that temporal orientations have an essential role in individuals' cognitions, emotions, motivation, and behaviours (Frank, 1939; Gjesme, 1979; Husman \& Lens, 1999; Lewin, 1935; Nuttin, 2014).

With respect to the orientation towards the present, previous studies indicate that focusing too much on the present moment may often lead to unproductive behaviours (Beal \& Crockett, 2010; Joireman et al., 2001, 2008; Strathman et al., 1994a; Strathman \& Joireman, 2005). Therefore, our findings indicating higher satisfaction among students who are able to sacrifice their current pleasures and wishes in order to accomplish future goals are in accordance with results showing that such individuals are more committed to learning and typically show less procrastinating behaviours during learning (Ferrari \& Tice, 2000; Specter \& Ferrari, 2000; Van Eerde, 2000), resulting in more favourable educational outcomes (Beal \& Crockett, 2010; Kauffman \& Husman, 2004; Manzi et al., 2010).

With regard to the orientation towards the future, it has been shown that individuals who are able to dissociate themselves from the present moment more often tend to show more positive motivation, as well as persistence and satisfaction from the undertaken actions than those with a stronger orientation towards the present moment (Husman \& Lens, 1999; Husman \& Shell, 2008; Zaleski, 1994). In the educational context, such individuals invest more efforts in learning and are better able to regulate their behaviours in order to achieve the desired academic goals (Husman \& Lens, 1999; Malka \& Covington, 2005; McInerney, 2004). Therefore, the results of the present study indicating that individuals who tend to focus more on the future also hold more positive expectations regarding future success were not surprising, as such individuals would be expected to prepare for tests in a timely and organised fashion given their ability to clearly define long-term goals and organise their behaviours accordingly (McInerney, 2004; Simons et al., 2004).

\section{Limitations of the Present Study and Directions for Future Research}

The interpretation of the obtained results may be influenced by several factors that can limit the generalisability of the reported findings. First, it is necessary to note the retrospective nature of this study, which was chosen because we wanted to capture the perspective of students in the self-reflection phase who had already had a chance to evaluate the results of their behaviours. However, 
this procedure may introduce a recall bias (Podsakoff et al., 2003) because the retrieval process is often influenced by the respondents' current states (Bradburn et al., 1987; Linton, 1982), suggesting that future studies should implement longitudinal designs and investigate all phases of the test-taking process. In addition, several variables assessed in the present study, in particular participants' satisfaction with acquired knowledge, ease of preparing for tests, and success optimism, were based on one-item estimates associated with limited reliability and validity. Therefore, these measures should be refined and further examined in future studies. Next, the gender distribution of participants in the present study was unbalanced, reflecting the above-average representation of female students in the college majors included within this study. As previous research has demonstrated the existence of gender differences with respect to students' learning approaches and academic achievement (Anderman \& Anderman, 1999; Baharudin \& Zulkefly, 2009; Bodill \& Roberts, 2013; Midgley \& Urdan, 1995; Patrick et al., 1999; Pomerantz et al., 2002), as well as some aspects of temporal perspectives (Petrocelli, 2003; Zimbardo \& Boyd, 1999; Zimbardo et al., 1997), the relevance of gender differences should be investigated with more scrutiny in future studies. Finally, these studies would benefit from further investigating the role of students' learning approaches as well as other characteristics in related aspects of their test preparation approaches and academic behaviours more generally. In doing so, it would be of great importance to focus on their objective outcomes as well as subjective beliefs regarding their accomplishments, and implement longitudinal research designs which would allow researchers to follow students as they transition from elementary to high school, and subsequently to college.

\section{Implications for Practitioners}

Practitioners, teachers and counsellors alike, often consider tests in terms of their ability to evaluate student knowledge and orient themselves primarily to test effectiveness and their outcomes. However, students' perception of the test-taking process, as well as their personal experiences related to this process should also be considered with regard to teaching across all educational levels. The results of the present study indicate differences with respect to the perception of the test-taking process among individuals who approach decision making and learning in different ways which should be considered by counsellors and teachers working with college students.

Specifically, although we may often consider student counselling centres as services dedicated to dealing with potential mental health issues (Kitzrow, 2003), it should be noted that these may also be used to promote students' more positive self-beliefs and constructive attributions in the academic domain 
(Perry et al., 2005; Perry et al., 1993), similar to the way these may be malleable in other domains (Di Fabio \& Kenny, 2011; Gist \& Mitchell, 1992; McNatt \& Judge, 2008). Comparable with this, interventions aimed at raising students' awareness of the relevance of considering future outcomes when engaging in present behaviours et al., 2014) may also be helpful in this context because this awareness should promote their timely preparation for tests. It can be speculated that better preparation would, in turn, result in higher satisfaction with the acquired knowledge and more positive expectations, which may facilitate students' preparation for future tests and result in more favourable educational outcomes as viewed by themselves as well as their teachers (McInerney, 2004).

Similarly, teachers may be advised that discussing students' experiences and perception of the test-taking process can, even without formal interventions, influence students' views and approaches to test-taking, as even small changes in attributions may sometimes result in measurable improvements within the academic context (Wilson et al., 2002). Therefore, the present findings, together with future studies addressing individual differences related to the way students approach and evaluate the test-taking process, should be considered in the context of higher education as they reveal important insights that can inform the practitioners regarding ways of aiding their students in achieving better educational outcomes.

\section{References}

Ainley, J., Foreman, J., \& Sheret, M. (1991). High school factors that influence students to remain in school. The Journal of Educational Research, 85(2), 69-8o. https://doi.org/10.1080/00220671.1991.107 02816

Anderman, L. H., \& Anderman, E. M. (1999). Social predictors of changes in students' achievement goal orientations. Contemporary Educational Psychology, 24(1), 21-37. https://doi.org/10.1006/ ceps.1998.0978

Appelt, K. C., Milch, K. F., Handgraaf, M. J., \& Weber, E. U. (2011). The decision making individual differences inventory and guidelines for the study of individual differences in judgment and decision-making research. Judgment and Decision Making, 6(3), 252-262.

Baharudin, R., \& Zulkefly, N. (2009). Relationships with father and mother, self-esteem and academic achievement among college students. American Journal of Scientific Research, 6, 86-94. Bandura, A. (1977). Self-efficacy: Toward a unifying theory of behavioral change. Psychological Review, 84(2), 191-215. https://doi.org/10.1037/0033-295X.84.2.191

Bandura, A. (1986). Social foundations of thought and action: A social cognitive theory. Prentice Hall. Bandura, A. (2006). Toward a psychology of human agency. Perspectives on Psychological Science, 1(2), 164-18o. https://doi.org/10.1111/j.1745-6916.2006.00o11.X 
Bandura, A., Barbaranelli, C., Caprara, G. V., \& Pastorelli, C. (1996). Multifaceted impact of selfefficacy beliefs on academic functioning. Child Development, 67(3), 1206-1222.

https://doi.org/10.2307/1131888

Beal, S. J., \& Crockett, L. J. (2010). Adolescents' occupational and educational aspirations and expectations: Links to high school activities and adult educational attainment. Developmental Psychology, 46(1), 258-265. https://doi.org/10.1037/aoo17416

Bembenutty, H., \& Karabenick, S. A. (2004). Inherent association between academic delay of gratification, future time perspective, and self-regulated learning. Educational Psychology Review, 16(1), 35-57. https://doi.org/10.1023/B:EDPR.0oooo12344.34008.5C

Bodill, K., \& Roberts, L. D. (2013). Implicit theories of intelligence and academic locus of control as predictors of studying behaviour. Learning and Individual Differences, 27, 163-166.

Bradburn, N. M., Rips, L. J., \& Shevell, S. K. (1987). Answering autobiographical questions: The impact of memory and inference on surveys. Science, 236(4798), 157-161. https://doi.org/ 10.1126/ science. 3563494

Brown, A. L. (1978). Knowing when, where, and how to remember: A problem of metacognition. In R. Glaser (Ed.), Advances in instructional psychology (Vol. 1, pp. 77-165). Erlbaum.

Bubic, A. (2015). The influence of considering the past, present, and future on college satisfaction.

Time \& Society. https://doi.org/10.1177/0961463X15577278

Covington, M. V. (2000). Goal theory, motivation, and school achievement: An integrative review. Annual Review of Psychology, 51(1), 171-200. https://doi.org/10.1146/annurev.psych.51.1.171 Cummins, R. A., \& Nistico, H. (2002). Maintaining life satisfaction: The role of positive cognitive bias. Journal of Happiness Studies, 3(1), 37-69. https://doi.org/10.1023/A:1015678915305

Di Fabio, A., \& Kenny, M. E. (2011). Promoting emotional intelligence and career decision making among Italian high school students. Journal of Career Assessment, 19(1), 21-34. https://doi. org/10.1177/1069072710382530

Dowson, M., \& McInerney, D. M. (2001). Psychological parameters of students' social and work avoidance goals: A qualitative investigation. Journal of Educational Psychology, 93(1), 35-42. https:// doi.org/10.1037/0022-0663.93.1.35

Dowson, M., \& McInerney, D. M. (2003). What do students say about their motivational goals?: Towards a more complex and dynamic perspective on student motivation. Contemporary Educational Psychology, 28(1), 91-113. https://doi.org/10.1016/So361-476X(02)ooo10-3

Eccles, J. S. (2005). Subjective task value and the Eccles et al. model of achievement-related choices. In A. J. Elliot \& C. S. Dweck (Eds.), Handbook of competence and motivation (pp. 105-121). Guilford Publication.

Eccles, J. S., \& Wigfield, A. (2002). Motivational beliefs, values, and goals. Annual Review of Psychology, 53(1), 109-132. https://doi.org/10.1146/annurev.psych.53.100901.135153

Ferrari, J. R., \& Tice, D. M. (200o). Procrastination as a self-handicap for men and women: A taskavoidance strategy in a laboratory setting. Journal of Research in Personality, 34(1), 73-83. https://doi. org/10.1006/jrpe.1999.2261 
Flavell, J. H. (1979). Metacognition and cognitive monitoring: A new area of cognitive-

developmental inquiry. American Psychologist, 34(10), 906-911.

https://doi.org/10.1037/0003-066X.34.10.906

Frank, L. K. (1939). Time perspectives. Journal of Social Philosophy, 4, 293-312.

Gist, M. E., \& Mitchell, T. R. (1992). Self-efficacy: A theoretical analysis of its determinants and malleability. Academy of Management Review, 17(2), 183-211.

https://doi.org/10.5465/AMR.1992.4279530

Gjesme, T. (1979). Future time orientation as a function of achievement motives, ability, delay of gratification, and sex. The Journal of Psychology, 101(2), 173-188.

https://doi.org/10.1080/00223980.1979.9915069

Hall, P. A., \& Fong, G. T. (2003). The effects of a brief time perspective intervention for increasing physical activity among young adults. Psychology and Health, 18(6), 685-706.

https://doi.org/o.1080/0887044031000110447

Husman, J., \& Lens, W. (1999). The role of the future in student motivation. Educational Psychologist, 34(2), 113-125. https://doi.org/10.1207/s15326985ep3402_4

Husman, J., \& Shell, D. F. (2008). Beliefs and perceptions about the future: A measurement of future time perspective. Learning and Individual Differences, 18(2), 166-175.

https://doi.org/10.1016/j.lindif.2007.08.001

Joireman, J. A., Balliet, D., Sprott, D., Spangenberg, E., \& Schultz, J. (2008). Consideration of future consequences, ego-depletion, and self-control: Support for distinguishing between CFC-Immediate and CFC-Future sub-scales. Personality and Individual Differences, 45(1), 15-21.

https://doi.org/10.1016/j.paid.2008.02.011

Joireman, J. A., Lasane, T. P., Bennett, J., Richards, D., \& Solaimani, S. (2001). Integrating social value orientation and the consideration of future consequences within the extended norm activation model of proenvironmental behaviour. British Journal of Social Psychology, 40(1), 133-155.

https://doi.org/10.1348/014466601164731

Kauffman, D. F., \& Husman, J. (2004). Effects of time perspective on student motivation: Introduction to a special issue. Educational Psychology Review, 16(1), 1-7.

https://doi.org/ 10.1023/B:EDPR.ooooo12342.37854.58

Kitzrow, M. A. (2003). The mental health needs of today's college students: Challenges and recommendations. Journal of Student Affairs Research and Practice, 41(1), 167-181.

Lewin, K. (1935). A dynamic theory of personality: Selected papers. McGraw-Hill.

Linton, M. (1982). Transformations of memory in everyday life. In U. Neisser (Ed.), Memory observed: Remembering in natural contexts (pp. 77-91). Freeman.

Maddux, J. E. (1999). Expectancies and the social-cognitive perspective: Basic principles, processes, and variables. In I. Kirsch (Ed.), How expectancies shape experience (pp. 17-39). American Psychological Association.

Maehr, M. L. (1984). Meaning and motivation: Toward a theory of personal investment. In R. E.

Ames \& C. Ames (Eds.), Research on motivation in education (Vol. 1, pp. 115-144). Academic Press. 
Maehr, M. L., \& Braskamp, L. A. (1986). The motivation factor: A theory of personal investment. Lexington Books/DC Heath and Com.

Malka, A., \& Covington, M. V. (2005). Perceiving school performance as instrumental to future goal attainment: Effects on graded performance. Contemporary Educational Psychology, 3o(1), 6o-8o. https://doi.org/10.1016/j.cedpsych.2004.04.001

Manzi, C., Vignoles, V. L., \& Regalia, C. (2010). Accommodating a new identity: Possible selves, identity change and well-being across two life-transitions. European Journal of Social Psychology, 4o(6), 970-984. https://doi.org/10.1002/ejsp.669

Marko, K. W., \& Savickas, M. L. (1998). Effectiveness of a career time perspective intervention. Journal of Vocational Behavior, 52(1), 106-119. https://doi.org/10.1006/jvbe.1996.1566 McInerney, D. M. (2004). A discussion of future time perspective. Educational Psychology Review, 16(2), 141-151. https://doi.org/10.1023/B:EDPR.00ooo26610.18125.a3

McInerney, D. M., Marsh, H. W., \& Yeung, A. S. (2002). Toward a hierarchical goal theory model of school motivation. Journal of Applied Measurement, 4(4), 335-357.

McInerney, D. M., Roche, L. A., McInerney, V., \& Marsh, H. W. (1997). Cultural perspectives on school motivation: The relevance and application of goal theory. American Educational Research Journal, 34(1), 207-236. https://doi.org/10.3102/00028312034001207

McInerney, D. M., \& Sinclair, K. E. (1991). Cross cultural model testing: Inventory of school motivation. Educational and Psychological Measurement, 51(1), 123-133.

https://doi.org/10.1177/0013164491511011

McInerney, D. M., \& Sinclair, K. E. (1992). Dimensions of school motivation: A cross-cultural validation study. Journal of Cross-Cultural Psychology, 23(3), 389-406.

https://doi.org/10.1177/0022022192233009

McInerney, D. M., Yeung, A. S., \& McInerney, V. (2000). Cross-cultural validation of the Inventory of School Motivation (ISM): Motivation orientations of Navajo and Anglo students. Journal of Applied Measurement, 2(2), 135-153.

McNatt, D. B., \& Judge, T. A. (2008). Self-efficacy intervention, job attitudes, and turnover: A field experiment with employees in role transition. Human Relations, 61(6), 783-810.

https://doi.org/o.1177/0018726708092404

Midgley, C., \& Urdan, T. (1995). Predictors of middle school students' use of self-handicapping strategies. The Journal of Early Adolescence, 15(4), 389-411.

https://doi.org/10.1177/0272431695015004001

Mok, M. M. C., \& Flynn, M. (2002). Determinants of students' quality of school life: A path model. Learning Environments Research, 5(3), 275-30o. https://doi.org/10.1023/A:1021924322950 Moore, M., \& Dahlen, E. R. (2008). Forgiveness and consideration of future consequences in aggressive driving. Accident Analysis \& Prevention, 40(5), 1661-1666.

https://doi.org/10.1016/j.aap.2008.05.007

Multon, K. D., Brown, S. D., \& Lent, R. W. (1991). Relation of self-efficacy beliefs to academic outcomes: A meta-analytic investigation. Journal of Counseling Psychology, 38(1), 30-38. 
https://doi.org/10.1037/0022-0167.38.1.30

Nilsen, H. (2009). Influence on student academic behaviour through motivation, self-efficacy and value-expectation: An action research project to improve learning. Issues in Informing Science and Information Technology, 6, 545-556.

Nuttin, J. R. (2014). Future time perspective and motivation: Theory and research method. Psychology Press.

Pajares, F. (2003). Self-efficacy beliefs, motivation, and achievement in writing: A review of the literature. Reading \& Writing Quarterly, 19(2), 139-158. https://doi.org/10.1080/10573560308222 Pajares, F., \& Urdan, T. C. (2006). Self-efficacy beliefs of adolescents. IAP.

Patrick, H., Ryan, A. M., \& Pintrich, P. R. (1999). The differential impact of extrinsic and mastery goal orientations on males' and females' self-regulated learning. Learning and Individual Differences, 11(2), 153-171. https://doi.org/10.1016/S1041-608o(oo)80o03-5

Perry, R. P. (1991). Perceived control in college students: Implications for instruction in higher education. In J. C. Smart (Ed.), Higher education: Handbook of theory and research (Vol. 7, pp. 1-56). Agathon.

Perry, R. P., Hladkyj, S., Pekrun, R. H., \& Pelletier, S. T. (2001). Academic control and action control in the achievement of college students: A longitudinal field study. Journal of Educational Psychology, 93(4), 776-789. https://doi.org/10.1037/0022-0663.93.4.776

Perry, R. P., Hall, N. C., \& Ruthig, J. C. (2005). Perceived (academic) control and scholastic attainment in higher education. In J. C. Smart (Ed.), Higher education: Handbook of theory and research (Vol. 20, pp. 363-436). Springer.

Perry, R. P., Hechter, F. J., Menec, V. H., \& Weinberg, L. E. (1993). Enhancing achievement motivation and performance in college students: An attributional retraining perspective. Research in Higher Education, 34(6), 687-723. https://doi.org/10.1007/BFoo992156

Petrocelli, J. V. (2003). Factor validation of the consideration of future consequences scale: Evidence for a short version. The Journal of Social Psychology, 143(4), 405-413.

https://doi.org/10.1080/00224540309598453

Peverly, S. T., Brobst, K. E., Graham, M., \& Shaw, R. (2003). College adults are not good at selfregulation: A study on the relationship of self-regulation, note taking, and test taking. Journal of Educational Psychology, 95(2), 335-346. https://doi.org/10.1037/0022-0663.95.2.335

Podsakoff, P. M., MacKenzie, S. B., Lee, J.-Y., \& Podsakoff, N. P. (2003). Common method biases in behavioral research: A critical review of the literature and recommended remedies. Journal of Applied Psychology, 88(5), 879-903. https://doi.org/10.1037/0021-9010.88.5.879

Pomerantz, E. M., Altermatt, E. R., \& Saxon, J. L. (2002). Making the grade but feeling distressed: Gender differences in academic performance and internal distress. Journal of Educational Psychology, 94(2), 396-404. https://doi.org/10.1037/0022-0663.94.2.396

Pressley, M., \& Ghatala, E. S. (1988). Delusions about performance on multiple-choice comprehension tests. Reading Research Quarterly, 23, 454-464. https://doi.org/10.2307/747643 Pressley, M., Ghatala, E. S., Woloshyn, V., \& Pirie, J. (1990). Sometimes adults miss the main ideas 
and do not realize it: Confidence in responses to short-answer and multiple-choice comprehension questions. Reading Research Quarterly, 25, 232-249. https://doi.org/10.2307/748004 Raboteg-Šarić, Z., Šakić, M., \& Brajša-Žganec, A. (2009). Kvaliteta života u osnovnoj školi: Povezanost sa školskim uspjehom, motivacijom i ponašanjem učenika [Quality of life in primary school: Connectedness with school achievement, motivation and student behavior]. Društvena Istraživanja, 18(4-5 (102-103)), 697-716.

Robbins, S. B., Lauver, K., Le, H., Davis, D., Langley, R., \& Carlstrom, A. (2004). Do psychosocial and study skill factors predict college outcomes? A meta-analysis. Psychological Bulletin, 130(2), 261-288. https://doi.org/10.1037/0033-2909.130.2.261

Schuitema, J., Peetsma, T., \& van der Veen, I. (2014). Enhancing student motivation: A longitudinal intervention study based on future time perspective theory. The Journal of Educational Research, $107(6), 467-481$. https://doi.org/10.1080/00220671.2013.836467

Schunk, D. H. (1990). Goal setting and self-efficacy during self-regulated learning. Educational Psychologist, 25(1), 71-86. https://doi.org/10.1207/s15326985ep2501_6

Schunk, D. H. (1991). Self-efficacy and academic motivation. Educational Psychologist, 26(3-4), 207-231. https://doi.org/10.1080/00461520.1991.9653133

Schunk, D. H., Pintrich, P. R., \& Meece, J. L. (2008). Motivation in education: Theory, research, and applications. Merrill-Prentice Hall.

Schutz, P. A., \& Davis, H. A. (200o). Emotions and self-regulation during test taking. Educational Psychologist, 35(4), 243-256. https://doi.org/10.1207/S15326985EP3504_03

Simons, J., Vansteenkiste, M., Lens, W., \& Lacante, M. (2004). Placing motivation and future time perspective theory in a temporal perspective. Educational Psychology Review, 16(2), 121-139.

https://doi.org/10.1023/B:EDPR.00ooo26609.94841.2f

Slavin, R. E. (1991). Educational psychology: Theory into practice. Allyn \& Bacon.

Sorić, I., \& Burić, I. (2010). Skala percipirane akademske kontrole [Scale of perceived academic control]. In I. Tucak-Junaković, V. Ćubela Adorić, A. Proroković, \& Z. Penezić (Eds.), Zbirka psihologijskih skala i upitnika $V$ (pp. 47-52). Sveučilište u Zadru.

Specter, M. H., \& Ferrari, J. R. (2000). Time orientations of procrastinators: Focusing on the past, present, or future? Journal of Social Behavior \& Personality, 15(5), 197-202.

Strathman, A., Boninger, D. S., Gleicher, F., \& Baker, S. M. (1994a). Constructing the future with present behavior: An individual difference approach. In Z. E. Zaleski (Ed.), The psychology of future orientation (pp. 107-119). Catholic University of Lublin Press.

Strathman, A., Gleicher, F., Boninger, D. S., \& Edwards, C. S. (1994b). The consideration of future consequences: Weighing immediate and distant outcomes of behavior. Journal of Personality and Social Psychology, 66(4), 742-752.

Strathman, A., \& Joireman, J. A. (2005). Understanding behavior in the context of time: Theory, research, and application. Lawrence Erlbaum.

Taber, B. J. (2013). Time perspective and career decision-making difficulties in adults. Journal of Career Assessment, 21(2), 200-209. https://doi.org/10.1177/1069072712466722 
Urdan, T. C., \& Maehr, M. L. (1995). Beyond a two-goal theory of motivation and achievement: A case for social goals. Review of Educational Research, 65(3), 213-243.

https://doi.org/10.3102/00346543065003213

Van Eerde, W. (200o). Procrastination: Self-regulation in initiating aversive goals. Applied Psychology, 49(3), 372-389. https://doi.org/10.1111/1464-0597.00021

Veenman, M. V., Van Hout-Wolters, B. H., \& Afflerbach, P. (2006). Metacognition and learning: Conceptual and methodological considerations. Metacognition and Learning, 1(1), 3-14.

https://doi.org/10.1007/s11409-006-6893-0

Wentzel, K. R. (1996). Social and academic motivation in middle school concurrent and long-term relations to academic effort. The Journal of Early Adolescence, 16(4), 390-406.

https://doi.org/10.1177/0272431696016004002

Wentzel, K. R. (1999). Social-motivational processes and interpersonal relationships: Implications for understanding motivation at school. Journal of Educational Psychology, 91(1), 76-97.

https://doi.org/10.1037/0022-0663.91.1.76

Wentzel, K. R., \& Wigfield, A. (1998). Academic and social motivational influences on students' academic performance. Educational Psychology Review, 10(2), 155-175.

https://doi.org/10.1023/A:1022137619834

Wilson, T. D., Damiani, M., \& Shelton, N. (2002). Improving the academic performance of college students with brief attributional interventions. In J. Aronson (Ed.), Improving Academic Achievement: Impact of Psychological Factors on Education (pp. 88-108). Academic Press.

Wigfield, A., \& Eccles, J. S. (2000). Expectancy-value theory of achievement motivation. Contemporary Educational Psychology, 25(1), 68-81. https://doi.org/10.1006/ceps.1999.1015 Wigfield, A., \& Eccles, J. S. (2002). The development of competence beliefs, expectancies for success, and achievement values from childhood through adolescence. In A. Wigfield \& J. S. Eccles (Eds.), Development of achievement motivation (pp. 91-120). Elsevier.

Zaleski, Z. E. (1994). Psychology of future orientation. Towarzystwa Naukowego KUL.

Zimbardo, P. G., \& Boyd, J. N. (1999). Putting time in perspective: A valid, reliable individualdifferences metric. Journal of Personality and Social Psychology, 77(6), 1271-1288. https://doi. org/10.1037/0022-3514.77.6.1271

Zimbardo, P. G., Keough, K. A., \& Boyd, J. N. (1997). Present time perspective as a predictor of risky driving. Personality and Individual Differences, 23(6), 1007-1023.

https://doi.org/10.1016/So191-8869(97)oo113-X

Zimmerman, B. J. (1995). Self-efficacy and educational development. In A. Bandura (Ed.), Selfefficacy in changing societies (pp. 202-231). Cambridge University Press.

Zimmerman, B. J. (1998). Developing self-fulfilling cycles of academic regulation: An analysis of exemplary instructional models. In D. H. Schunk \& B. J. Zimmerman (Eds.), Self-regulation of learning and performance: Issues and educational applications (pp. 3-21). Lawrence Erlbaum Associates. Zimmerman, B. J. (2000). Attaining self-regulation: A social cognitive perspective. In M. Boekaerts, P. R. Pintrich, \& M. Zeidner (Eds.), Handbook of self-regulation (pp. 13-39). Academic Press. 
Zimmerman, B. J., \& Kitsantas, A. (1997). Developmental phases in self-regulation: Shifting from process goals to outcome goals. Journal of Educational Psychology, 89(1), 29-36.

https://doi.org/10.1037/0022-0663.89.1.29

\section{Biographical note}

Andreja Bubić, PhD, is an Associate Professor in the field of educational and cognitive sciences at the Faculty of Humanities and Social Sciences, University of Split. Her main research interests include decision making, judgment and other cognitive processes as well as their implications in the educational setting. 